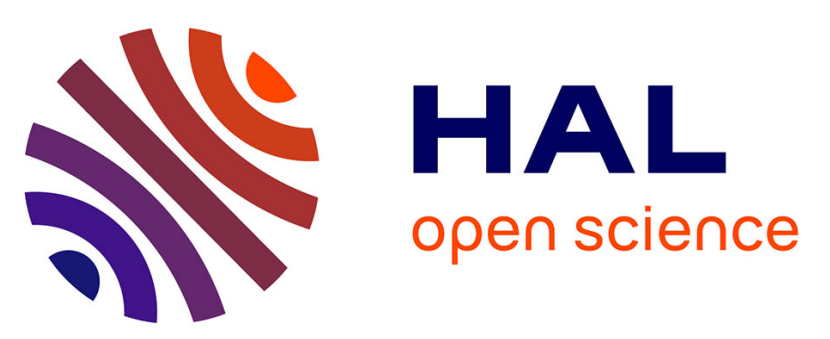

\title{
Foliar or root exposures to smelter particles: Consequences for lead compartmentalization and speciation in plant leaves
}

Eva Schreck, Vincent Dappe, Géraldine Sarret, Sophie Sobanska, Dorota

Nowak, Jakub Nowak, Elżbieta Anna Stefaniak, Valérie Magnin, Vincent Ranieri, Camille Dumat

\section{To cite this version:}

Eva Schreck, Vincent Dappe, Géraldine Sarret, Sophie Sobanska, Dorota Nowak, et al.. Foliar or root exposures to smelter particles: Consequences for lead compartmentalization and speciation in plant leaves. Science of the Total Environment, 2014, 476-477, pp.667-676. hal-01585017

\section{HAL Id: hal-01585017 https://hal.science/hal-01585017}

Submitted on 11 Sep 2017

HAL is a multi-disciplinary open access archive for the deposit and dissemination of scientific research documents, whether they are published or not. The documents may come from teaching and research institutions in France or abroad, or from public or private research centers.
L'archive ouverte pluridisciplinaire HAL, est destinée au dépôt et à la diffusion de documents scientifiques de niveau recherche, publiés ou non, émanant des établissements d'enseignement et de recherche français ou étrangers, des laboratoires publics ou privés. 


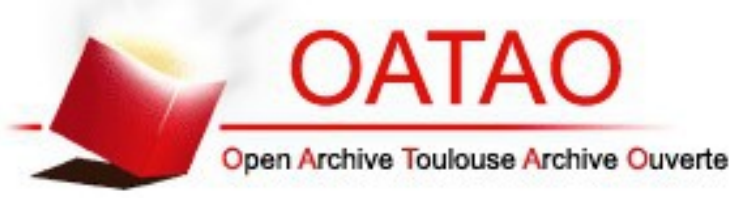

\section{Open Archive TOULOUSE Archive Ouverte (OATAO)}

OATAO is an open access repository that collects the work of Toulouse researchers and makes it freely available over the web where possible.

This is an author-deposited version published in : http://oatao.univ-toulouse.fr/ Eprints ID : 11343

To link to this article : DOI :10.1016/j.scitotenv.2013.12.089 URL : http://dx.doi.org/10.1016/j.scitotenv.2013.12.089

To cite this version : Schreck, Eva and Dappe, Vincent and Sarret, Géraldine and Sobanska, Sophie and Nowak, Dorota and Nowak, Jakub and Stefaniak, Elżbieta Anna and Magnin, Valérie and Ranieri, Vincent and Dumat, Camille Foliar or root exposures to smelter particles: Consequences for lead compartmentalization and speciation in plant leaves. (2014) Science of the Total Environment, Vol. 476477. pp. 667-676. ISSN 0048-9697

Any correspondance concerning this service should be sent to the repository administrator: staff-oatao@listes-diff.inp-toulouse.fr 


\section{Foliar or root exposures to smelter particles: Consequences for lead compartmentalization and speciation in plant leaves}

\section{Eva Schreck ${ }^{\mathrm{a}, \mathrm{b}, \mathrm{c}}$, Vincent Dappe ${ }^{\mathrm{d}}$, Géraldine Sarret ${ }^{\mathrm{e}}$, Sophie Sobanska ${ }^{\mathrm{d}}$, Dorota Nowak ${ }^{\mathrm{f}}$, Jakub Nowak ${ }^{\mathrm{f}}$, Elżbieta Anna Stefaniak ${ }^{\mathrm{f}}$, Valérie Magnin ${ }^{\mathrm{e}}$, Vincent Ranieri ${ }^{\mathrm{g}}$, Camille Dumat ${ }^{\mathrm{a}, \mathrm{b}, *}$}

a Université de Toulouse, INP, UPS, EcoLab (Laboratoire Ecologie Fonctionnelle et Environnement), ENSAT, Avenue de l'Agrobiopole, 31326 Castanet-Tolosan, France

b CNRS, EcoLab, 31326 Castanet-Tolosan, France

c Géosciences Environnement Toulouse (GET), Observatoire Midi Pyrénées, Université de Toulouse, CNRS, IRD, 14 Avenue E. Belin, F-31400 Toulouse, France

' LASIR (UMR CNRS 8516), Université de Lille 1, Bât. C5, 59655 Villeneuve d'Ascq Cedex, France

e ISTerre, UMR 5275, Université Grenoble I, CNRS, F-38041 Grenoble, France

${ }^{\mathrm{f}}$ Department of Chemistry, John Paul II Catholic University of Lublin, Al. Kraśnicka 102, 20-718 Lublin, Poland

${ }^{g}$ CEA-INAC, 17 rue des Martyrs, 38054 Grenoble Cedex 9, France

\section{H I G H L I G H T S}

- Plants were exposed to factory process particles via atmosphere or soil transfer.

- Pathways of $\mathrm{Pb}$ uptake were investigated using microscopy and spectroscopy.

- Contrary to lettuces, $\mathrm{Pb}$ speciation has changed in the leaf surfaces of rye-grass.

- In the case of root exposure, pyromorphite was formed in the leaves of ryegrass.

- $\mathrm{Pb}$ compartmentalization and speciation depend on transfer way and plant species.
G RA P H I C A L A B S TRACT

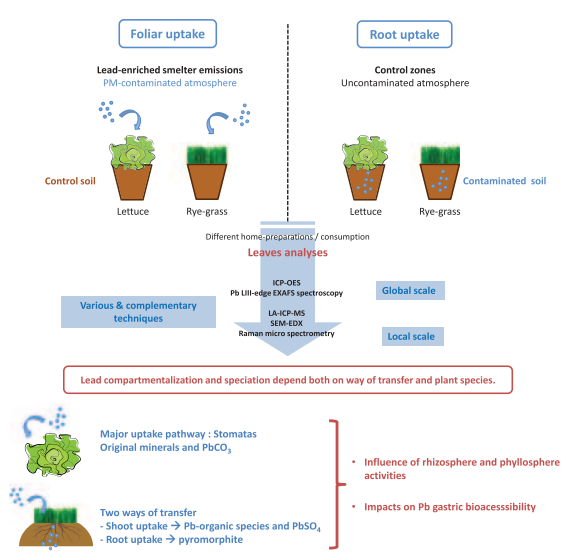

\section{A B S T R A C T}

In urban areas with high fallout of airborne particles, metal uptake by plants mainly occurs by foliar pathways and can strongly impact crop quality. However, there is a lack of knowledge on metal localization and speciation in plants after pollution exposure, especially in the case of foliar uptake. In this study, two contrasting crops, lettuce (Lactuca sativa $\mathrm{L}$.) and rye-grass (Lolium perenne $\mathrm{L}$.), were exposed to $\mathrm{Pb}$-rich particles emitted by a Pb-recycling factory via either atmospheric or soil application. Pb accumulation in plant leaves was observed for both ways of exposure. The mechanisms involved in $\mathrm{Pb}$ uptake were investigated using a combination of microscopic and spectroscopic techniques (electron microscopy, laser ablation, Raman microspectroscopy, and X-ray absorption spectroscopy).

The results show that $\mathrm{Pb}$ localization and speciation are strongly influenced by the type of exposure (root or shoot pathway) and the plant species. Foliar exposure is the main pathway of uptake, involving the highest concentrations in plant tissues. Under atmospheric fallouts, Pb-rich particles were strongly adsorbed on the leaf surface of both plant species. In lettuce, stomata contained $\mathrm{Pb}$-rich particles in their apertures, with some deformations of guard cells. In addition to $\mathrm{PbO}$ and $\mathrm{PbSO}_{4}$, chemical forms that were also observed in pristine particles, new

\footnotetext{
* Corresponding author at: EcoLab, INP-ENSAT, Avenue de l'Agrobiopôle, BP 32607, Auzeville Tolosane, 31326 Castanet-Tolosan, France. Tel.: + 335343239 03; fax: + 33534323901. E-mail address: camille.dumat@ensat.fr (C. Dumat).
} 
species were identified: organic compounds (minimum 20\%) and hexagonal platy crystals of $\mathrm{PbCO}_{3}$. In rye-grass, the changes in $\mathrm{Pb}$ speciation were even more egregious: $\mathrm{Pb}$-cell wall and $\mathrm{Pb}$-organic acid complexes were the major species observed.

For root exposure, identified here as a minor pathway of $\mathrm{Pb}$ transfer compared to foliar uptake, another secondary species, pyromorphite, was identified in rye-grass leaves. Finally, combining bulk and spatially resolved spectroscopic techniques permitted both the overall speciation and the minor but possibly highly reactive lead species to be determined in order to better assess the health risks involved.

\section{Introduction}

Atmospheric contamination by airborne particles (PM) enriched with metals has increased in regions with intense industrial activity (Douay et al., 2008; Perrone et al., 2010; Polichetti et al., 2009; Pruvot et al., 2006) and different megalopoleis in the world, particularly in Asia, Africa, and Latin America (Moffet et al., 2008; Park and Dam, 2010; Sammut et al., 2010; Shi et al., 2012; Waheed et al., 2011). Health risks associated with these atmospheric contaminations may arise mainly from inhalation of particles and consumption of polluted vegetables (Morman and Plumlee, 2013). For example, in industrial areas, $\mathrm{Pb}$ concentrations in crop plant tissues were reported to be two orders of magnitude higher than the European threshold of $0.3 \mathrm{mg} \mathrm{Pb} \mathrm{kg}-1$ fresh weight (Caggiano et al., 2005; Gonzalez-Miqueo et al., 2010; Honour et al., 2009; Tomasevic et al., 2005).

Metals can be accumulated in plant leaves through both root transfer and translocation (Estrella-Gómez et al., 2009; Piechalak et al., 2002; Uzu et al., 2009; Yanqun et al., 2004; Zhang et al., 2008) and/or foliar transfer after deposition of atmospheric particles on the leaf surfaces (Schreck et al., 2012a, and references therein). According to the pollution context, the foliar transfer of metals can be neglected, or in contrast appears as the main pathway of pollution, particularly when ultra-fine particles interact with plant leaves (De Temmerman et al., 2012; Feng et al., 2011; Hu et al., 2011; Schreck et al., 2012a) and especially as lead has relatively low mobility in soil and is generally weakly phytoavailable by root uptake. Recently, working on lead uptake, Schreck et al. (2013) showed that root and shoot metal uptake pathways are independent, with an additive effect in terms of phytotoxicity. However, even if the foliar pathway is better known nowadays, mechanisms involved in metal uptake, transfer, and trafficking in leaf tissues are still less investigated (Zangi and Filella, 2012). The type of exposure (root or shoot) may have different impacts on both metal compartmentalization (distribution at the tissue and cellular scale) and speciation in plants (Birbaum et al., 2010; Lei et al., 2008; Raskin et al., 1994; Sarret et al., 2013) and consequently metal bioavailability and toxicity. Thus, supplementary studies are needed to compare the two pathways of exposure in terms of metal transfer, their localization and speciation in plant tissues, and finally their environmental and health impacts.

Thus, the aim of this present study was to compare $\mathrm{Pb}$ compartmentalization and speciation in crops cultivated in the vicinity of a secondary $\mathrm{Pb}$ smelter and contaminated by $\mathrm{Pb}$-enriched particles via either atmosphere-plant or soil-plant pathways.

In order to highlight the involved changes potentially occurring in the phyllosphere or rhizosphere and then in the plant (with possible bio-transformations), two morphologically contrasting plant species were chosen: Lactuca sativa L. (lettuce, cultivar Batavia), with large, soft, frilly, and smooth leaves forming a loose leaf head, and Lolium perenne L. (rye-grass), with smooth and glossy leaves on the lower surface and parallel sides and prominent parallel veins on the upper surface.

These two plants are relevant models in terms of sanitary risk assessment, and are handled differently depending on their use and consumption. L. sativa $\mathrm{L}$. is one of the most frequently self-grown vegetables, whereas L. perenne $\mathrm{L}$. is consumed as fodder by cattle, with possible human impacts through dairy products and meat (Schreck et al., 2012a). Pb compartmentalization and speciation were studied at various scales, from macro- to micro- and molecular-level scales. After carrying out bulk inductively coupled plasma mass spectrometry (ICP-MS) analyses, $\mathrm{Pb}$ concentrations in leaf spots were determined by laser ablation (LA)-ICP-MS. Major Pb chemical forms were determined by Pb LIIIedge X-ray absorption spectroscopy (XAS), and $\mathrm{Pb}$ speciation at the microscopic scale was studied by scanning electronic microscopy coupled with energy dispersive X-ray microanalysis (SEM-EDX) and Raman microspectrometry (RMS). Pristine and aged particles from the secondary $\mathrm{Pb}$ smelter were also studied. To our knowledge, this is the first comparison of metal compartmentalization and speciation performed with an unprecedented combination of techniques as a function of the exposure pathway: soil versus atmospheric pollution, and in addition this study was done on plants from a field experiment.

\section{Materials and methods}

\subsection{Description of the field exposure area and characterization of atmospheric fallouts}

Plant exposure experiments were performed in the courtyard of a secondary $\mathrm{Pb}$ smelter that recycles car batteries, located in the southwest of France in the peri-urban area of Toulouse $\left(43^{\circ} 38^{\prime} 12^{\prime \prime} \mathrm{N}\right.$, $01^{\circ} 25^{\prime} 34^{\prime \prime} \mathrm{E}$ ). According to the French authorities (DREAL), the yearly emission of the smelter industry is $328 \mathrm{~kg}$ of total suspended particles. These emitted PMs have been previously characterized (Uzu et al., 2011). The size distribution of PM is mainly in the $1-100 \mu \mathrm{m}$ range ( $89 \%$ by volume fraction) with $9,50,20$, and $21 \%$ in the $\mathrm{PM}_{>10}, \mathrm{PM}_{10}$, $\mathrm{PM}_{2.5}$, and $\mathrm{PM}_{1}$ fractions, respectively. $\mathrm{Pb}$ is the major element in these atmospheric fallouts, comprising $33 \%$ of the total metal content, and its speciation was found to be mainly $\mathrm{PbS}, \mathrm{PbSO}_{4}, \mathrm{PbO} \cdot \mathrm{PbSO}_{4}$, and $\mathrm{PbO}$ (Uzu et al., 2011). During the vegetable exposure experiments, $\mathrm{Pb}$ concentration in industrial atmospheric fallouts was controlled in the smelter courtyard by collecting wet depositions in Owen gauges (Taylor and Witherspoon, 1972), following the procedure described by Gandois et al. (2010), Munksgaard and Parry (1998), and Schreck et al. (2012b).

\subsection{Plant characteristics and exposure experiments}

Two separate experiments, that is, foliar and root metal transfers, were performed on both lettuce and rye-grass.

For the root transfer experiment, plants were cultivated individually in 5-l pots each containing $4 \mathrm{~kg}$ of soil collected in the vicinity of the smelter facility. The physico-chemical properties of the soil were previously characterized: $\mathrm{pH}_{\text {water }}=8.5, \mathrm{CEC}=6.9 \mathrm{cmol}^{(+)} \mathrm{kg}^{-1}$, amounts of soil organic matter and carbonates $\left(\mathrm{CaCO}_{3}\right)$ were respectively 6 and $4 \mathrm{~g} \mathrm{~kg}^{-1}$. This soil was contaminated by metals and metalloids due to atmospheric deposition with a concentration of $\mathrm{Pb}$ of $2000 \mathrm{mg} \mathrm{kg}^{-1}$ of dried soil. These plants were cultivated under an unpolluted atmosphere. Twenty-five plants of each species were cultivated for six weeks.

For the foliar transfer experiment, 45 pots, containing one plant each, were placed for six weeks in the smelter courtyard and exposed to $\mathrm{Pb}$ atmospheric fallouts. The $\mathrm{Pb}$ concentration in soil was checked and found to be less than $25.5 \pm 1.6 \mathrm{mg} \mathrm{kg}{ }^{-1}$ of dried soil. A geotextile membrane was placed on the top of the soil to protect it from atmospheric fallouts and thus to avoid soil contamination and metal transfer 
via root uptake, as described by Schreck et al. (2012a,b) and Uzu et al. (2010).

Light, temperature, humidity, and pluviometry were controlled during the whole of the experiment as reported by Schreck et al. (2012b) in order to reproduce the uptake pathways in the two separate experiments.

After six weeks of exposure, 10 plants of each species from the two experiments were harvested, and fresh shoot biomasses were measured. Only aerial parts were studied in order to focus on edible parts and the assessment of the risk involved.

Leaves were prepared for further analyses according to a human (lettuce) or animal (rye-grass) ingestion scenario for a better assessment of the health risks involved. A two-step washing method with deionized water was performed for lettuce shoots (Birbaum et al., 2010; Uzu et al., 2010), whereas rye-grass was not washed in order to reproduce the scenario of consumption by cattle. Plants were then pooled, and aliquots were taken for elemental analyses, XAS, and microscopic observations.

\subsection{Total $\mathrm{Pb}$ concentrations in plants leaves}

Plant tissues were oven-dried at $40{ }^{\circ} \mathrm{C}$ for $72 \mathrm{~h}$. Mineralization was performed in aqua regia (mixture of $1 / 4 \mathrm{HNO}_{3}$ and $3 / 4 \mathrm{HCl}$ ) at $80{ }^{\circ} \mathrm{C}$ for $4 \mathrm{~h}$ with a Digiprep ${ }^{\circledR}$ instrument (produced by SCP Science), which is a block digestion system allowing a high temperature and fast and uniform digestion of plant samples. Pb concentrations were measured by inductively coupled plasma-optical emission spectrometry (ICP-OES) (IRIS Intrepid II XXDL). Each sample was analyzed in triplicate and method control was performed with blank samples submitted to the same treatment (mineralization and assay). The limits of detection and quantification of $\mathrm{Pb}$ concentrations were 0.3 and $0.4 \mu \mathrm{gl}^{-1}$, respectively (Schreck et al., 2012a,b). The accuracy of measurements was checked using reference materials: Virginia tobacco leaves, CTA-VTL-2, ICHTJ, and TM-26.3 certified reference material from the National Water Research Institute, Canada. The concentrations found were within $98 \%$ of the certified values.

Metal concentrations in plants were subjected to statistical analysis. An analysis of variance (ANOVA), using the software Statistica, Edition'98 (StatSoft Inc., Tulsa, OK) was performed on the measured values. Significant differences ( $\mathrm{p}$-value $<0.05$ ) were determined by the LSD Fisher test.

\subsection{Global enrichment factor (GEF) and bioaccumulation factor (BF)}

The global enrichment factor (GEF) has been calculated to determine the degree of metal accumulation in leaves of plants grown on a contaminated site (with soil or atmospheric transfer) with respect to uncontaminated sites (Chopra and Pathak, 2013; Ngole, 2011; Singh et al., 2010). Thus, GEF was calculated as:

GEF

$[\mathrm{Pb}]$ in leaves of plants grown on contaminated site (Soil or Atmosphere) [Pb]in leaves of plants grown on control site(Soil or Atmosphere)

where $[\mathrm{Pb}]=\mathrm{Pb}$ concentration in plant leaves in $\mathrm{mg} \mathrm{Pb} \mathrm{kg}^{-1}$ of dry weight (DW).

The GEF method calculation normalizes the measured metal to the metal content contribution from natural sources. An internal normalization was applied with a known background element such as elemental Mg.

The bioaccumulation factor (BF) was determined as the ratio of $\mathrm{Pb}$ concentration in plant leaves and $\mathrm{Pb}$ concentrations in contaminated soil as follows:

$\mathrm{BF}=\underline{[\mathrm{Pb}] \text { in leaves of plants grown on contaminated soil }}$ $[\mathrm{Pb}]$ in contaminated soil where $[\mathrm{Pb}]=\mathrm{Pb}$ concentration in plant leaves or in contaminated soil ( $\mathrm{mg} \mathrm{Pb} \mathrm{kg}{ }^{-1}$ of DW).

Thus, $\mathrm{BF}$ is an indicative factor of root transfer.

\subsection{Metal concentrations in Pb-rich leaf spots determined by LA-ICP-MS}

LA-ICP-MS measurements were performed on leaves of $L$. sativa L. and L. perenne L. contaminated by atmospheric fallouts by using an ICP-MS (Thermo Fisher Scientific X Series 2 ICP-MS) with a collision cell, coupled to a laser ablation system (New Wave UP $213 \mathrm{~nm}$ ). The dried leaf surfaces without further preparation were ablated by NdYAG ultraviolet laser (wavelength: $213 \mathrm{~nm}$; repetition frequency: $20 \mathrm{~Hz}$; spot size: $15 \mu \mathrm{m}$ - single points; laser power: $30 \%$; dwell time: $2 \mathrm{~s}$ ) and then transported by high purity helium as a carrier gas from the super cell into the spectrometer (He flow rate: $950 \mathrm{ml} / \mathrm{min}$ ). The instrumental response was measured in counts per second (Cps) for the following isotopes: first $\mathrm{Pb}\left({ }^{206} \mathrm{~Pb},{ }^{207} \mathrm{~Pb}\right.$, and $\left.{ }^{208} \mathrm{~Pb}\right)$ and then ${ }^{24} \mathrm{Mg},{ }^{39} \mathrm{~K},{ }^{40} \mathrm{Ca},{ }^{23} \mathrm{Na},{ }^{27} \mathrm{Al},{ }^{29} \mathrm{Si},{ }^{31} \mathrm{P},{ }^{33} \mathrm{~S}$, and ${ }^{35} \mathrm{Cl}$.

The ratios of $\mathrm{Pb}$ isotopes' intensities were related to $\mathrm{Mg}$. $\mathrm{Mg}$ is considered as a background element in plant tissues, and therefore it was used to calculate local enrichment factors (LEFs). The reference ratio of $\mathrm{Pb}_{\text {tot }} / \mathrm{Mg}$ was calculated on the base of the intensity ratio for $\mathrm{Pb}$-free spots. Areas of interest were selected based on the visual aspect of the surface leaves observed on optical microscopy images. Then, plain tissue of the leaves without any visible particle or darkening (defined here as "green area: ga"), necroses (necrotic areas: na), and particles deposited on the surface (dark spots: ds) were distinguished and analyzed. In order to assess the representative metal concentration in leaf spots, 10 analytical points for plain tissues, necroses, and dark spots were investigated for each leaf. The spots ablated with a laser were selected to represent the surface heterogeneity of leaves from lettuce and rye-grass species.

2.6. Study of Pb speciation in leaves by X-ray absorption spectroscopy (XAS)

XAS experiments were performed on the FAME beamline BM30 at the European Synchrotron Radiation Facility (ESRF, Grenoble, France). The beamline was equipped with a $\mathrm{Si}$ (111) double crystal monochromator, a 30-element solid state Canberra detector for fluorescence mode, and a diode for transmission mode. Pb speciation was studied in plant leaves after exposure as well as in pristine and two-year-old particles.

Reference $\mathrm{Pb}$ minerals included metallic $\mathrm{Pb}, \mathrm{PbS}, \mathrm{PbSO}_{4}, \alpha$ - and $\beta$ $\mathrm{PbO}, \mathrm{PbCO}_{3}$, and $\mathrm{Pb}_{3}(\mathrm{OH})_{2}\left(\mathrm{CO}_{3}\right)_{2}$, and pyromorphite $\mathrm{Pb}_{5}\left(\mathrm{PO}_{4}\right)_{3} \mathrm{Cl}$ (or chloropyromorphite). They were ground, diluted in $\mathrm{N}_{2}$, and pressed into 5-mm-diameter pellets. Sorbed and complexed $\mathrm{Pb}$ species included $\mathrm{Pb}$-sorbed ferrihydrite containing $2 \%$ weight $\mathrm{Pb}$ prepared at $\mathrm{pH} 7.3, \mathrm{~Pb}-$ sorbed birnessite containing $2 \%$ weight $\mathrm{Pb}$ prepared at $\mathrm{pH} 6.5$, and $\mathrm{Pb}-$ pectin containing $0.8 \%$ weight $\mathrm{Pb}$. They were prepared in solution, freeze-dried, pressed into pellets, and re-humidified before the XAS measurements were carried out. $\mathrm{Pb}$ references in aqueous solution included free $\mathrm{Pb}^{2+}\left[20 \mathrm{mM} \mathrm{Pb}\left(\mathrm{NO}_{3}\right)_{2}, \mathrm{pH} 4.0\right]$ as well as $\mathrm{Pb}$ complexed to citrate $\left[10 \mathrm{mM} \mathrm{Pb}\left(\mathrm{NO}_{3}\right)_{2}, 100 \mathrm{mM}\right.$ Na citrate, $\mathrm{pH}$ 5.4] and malate [10 mM Pb( $\left.\mathrm{NO}_{3}\right)_{2}, 100 \mathrm{mM} \mathrm{Na}$ malate, $\mathrm{pH}$ 5.0]. Glycerol (20\% in volume) was added to the solution in order to avoid the formation of crystal ice. Pristine and aged particles were prepared like the Pb reference compounds.

Plant leaves were flash frozen in isopentane and transferred in a mortar cooled with liquid $\mathrm{N}_{2}$, and the frozen powder was pressed into pellets in liquid $\mathrm{N}_{2}$. Pellets were transferred in a He cryostat cooled at $10 \mathrm{~K}$ for XAS data acquisition. Spectra were recorded in fluorescence mode. Five to ten spectra of $30 \mathrm{~min}$ each were recorded for each sample, and the beam was moved between each spectrum to limit possible radiation damage. Data from each detector channel were inspected for glitches or dropouts before inclusion in the final average. 
XAS data extraction treatment was done using ATHENA software (Ravel and Newville, 2005). X-ray absorption near-edge structure (XANES) spectra were calibrated by taking the inflection point of metallic $\mathrm{Pb}$ at 13,035.0 eV. Normalized XANES and extended X-ray absorption fine structure (EXAFS) spectra were treated by linear combination fits of reference compounds' spectra as described previously (Huguet et al. 2012). The quality of the fits was evaluated by the normalized sum of squares of residuals. For the XANES part, no $\mathrm{E}_{0}$ shift or slope correction was allowed. The spectrum for the pristine particles was included in the library of reference compounds for the fit of the aged particles, and both the pristine and aged particles were used as reference compounds for the fit of the plant spectra. Principal component analysis was not used because the set of spectra was too limited.

\subsection{Identification of Pb-enriched area by SEM-EDX and Raman microspectroscopy (RMS)}

Environmental SEM-EDX measurements using a Quanta $200 \mathrm{FE}$ instrument equipped with a Quantax EDX detector were carried out to investigate the morphology and elemental distribution of the $\mathrm{Pb}$ enriched areas observed on the leaf surfaces. Five samples of each exposure condition and plant species were observed in order to check and validate our observations. All the leaves were dried and fixed on a carbon substrate without any further preparation before analysis. The apparatus was operated in low-vacuum mode ( 133 Pa) at $25 \mathrm{kV}$.

RMS was used to provide molecular characterization of particles deposited onto surface leaves. RMS measurements were carried out with a LabRAM HR UV spectrometer (Horiba, Jobin Yvon) using a $40 \times$ Mitutoyo objective. The Raman scattering was excited with the $325 \mathrm{~nm}$ UV laser and the spatial resolution was less than $1 \mu \mathrm{m}^{3}$. Measurements were carried out without any further preparation of vegetable samples and focused on metal-enriched areas previously observed by SEM-EDX. For identification of molecular species, the experimental spectra (band wavenumbers and relative intensities) were compared with reference spectra acquired for pure compounds.

The SEM-EDX and RMS were performed on the adaxial faces of the leaves of vegetables contaminated by atmospheric deposition.

\section{Results}

3.1. Total Pb concentrations in leaves, global enrichment factors (GEFs), and bioaccumulation factors (BFs)

Table 1 reports $\mathrm{Pb}$ concentrations in plant leaves and enrichment and bioaccumulation factors for the two plant species and foliar or root exposure (with the same exposure time). Significantly higher metal concentrations $(p<0.001)$ were observed in exposed plants as compared to controls, regardless of the type of exposure. Pb leaf content was five (for rye-grass) and eight times (for lettuce) higher for foliar exposure than for root exposure (Table 1). The higher value was observed for unwashed rye-grass leaves exposed to atmospheric fallouts (700 $\mathrm{mg} \mathrm{kg}^{-1}$ of dried shoots) whereas the lower value was observed for lettuce leaves exposed to polluted soil $\left(35.6 \mathrm{mg} \mathrm{kg}^{-1}\right.$ of dried shoots). For the foliar exposure, a four-fold higher $\mathrm{Pb}$ concentration was observed in the leaves of rye-grass as compared to lettuce (Table 1). Interestingly, in the case of foliar exposure, the calculated GEF is similar for the two species, since the $\mathrm{Pb}$ content in control leaves is 3.8 times higher for rye grass than for lettuce. For the root exposure, BFs were rather low $(<0.05)$, and a higher $\mathrm{Pb}$ content (more than double) was also observed in rye-grass leaves as compared to lettuce leaves.

3.2. Metal concentrations in particle-rich leaf spots determined by LA-ICPMS

The LA-ICP-MS results of ${ }^{24} \mathrm{Mg},{ }^{39} \mathrm{~K},{ }^{40} \mathrm{Ca},{ }^{23} \mathrm{Na},{ }^{27} \mathrm{Al},{ }^{29} \mathrm{Si},{ }^{31} \mathrm{P},{ }^{33} \mathrm{~S},{ }^{35} \mathrm{Cl}$, and $\mathrm{Pb}$ concentrations found in lettuce and rye-grass leaves in spots contaminated by atmospheric fallouts are reported in Supporting information S1. Supporting information S1a and S1b show the normalized mass spectra of selected ablated spots on the lettuce leaves and rye-grass, respectively. For all leaf samples, ${ }^{39} \mathrm{~K},{ }^{40} \mathrm{Ca}$, Pb, and ${ }^{40} \mathrm{Si}$ exhibited the highest intensities in the mass spectra.

In lettuce leaves, the highest $\mathrm{Pb}$ concentration was found in the spots with visible fine individual particles $(<1 \mu \mathrm{m})$ trapped on the surface (ds4 and ds1) and in necrotic zones (na1, na2, and na3). A moderate $\mathrm{Pb}$ concentration was also detected in clean parts of the leaves (ga3, ga4, and ga2).

Local enrichment factors (LEFs) were evaluated using the $\mathrm{Pb}_{\text {tot }} / \mathrm{Mg}$ ratio. The value for the control is 0.068 (with $19.066 \%$ relative standard deviation, RSD). LEFs for the spots are listed in Table 2.

LEF values ranged from 0.7 to 1286 in dark spots, 0.8 to 10.4 in necrotic areas, and 1 to 22 in green areas. Moreover, LEF $>1$ was also found close to leaf veins, with LEF varying between 2.2 and 6 . The isotopic ratio for three $\mathrm{Pb}$ isotopes $\left({ }^{206} \mathrm{~Pb},{ }^{207} \mathrm{~Pb}\right.$, and ${ }^{208} \mathrm{~Pb}$ ) appeared relatively uniform. The average ratio for ${ }^{206} \mathrm{~Pb} /{ }^{207} \mathrm{~Pb}$ and ${ }^{208} \mathrm{~Pb} /{ }^{206} \mathrm{~Pb}$ varied slightly from the reference value recorded on pristine particles and bulk samples of lettuce leaves, but the difference did not exceed $20 \%$. The average ratio ${ }^{208} \mathrm{~Pb} /{ }^{207} \mathrm{~Pb}$ was in very good agreement with the reference.

In rye-grass leaves, the highest $\mathrm{Pb}$ concentrations were not only found in dark spots corresponding to particles trapped on the leaf surface (see Supporting information S1b, spots ds3, ds4, ds8, ds6, and ds5), but also in the plain tissue (ga) without any visible changes on the surface (ga3, ga2). One spot with $99 \% \mathrm{~Pb}$ comprising the total intensity of the mass spectrum is not presented in S1b due to the exceptionally high level of $\mathrm{Pb}$ in this spot. This spot corresponds to a coarse individual Pb-rich particle $(>10 \mu \mathrm{m})$ freshly deposited on the leaf surface. LEFs are shown in Table 2. In dark spots, LEF values range from 3.1 to 2562.6, showing a strong variation of $\mathrm{Pb}$ concentration, which is likely related to the particle sizes in enriched spots. Unaffected areas (i.e. ga) always showed a detectable $\mathrm{Pb}$ signal, suggesting that $\mathrm{Pb}$ had diffused from the surface within the leaf tissue. The LEF values vary between 0.6 and 34.8, indicating a variation in concentration within the leaves.

Table 1

Total lead concentrations, global enrichment factors (GEF) and bioaccumulation factors (BF) in plant shoots after 6 weeks of exposure. Results are expressed according to the way of transfer (i.e. roots vs shoots). Values are given as a mean of ten replicates $( \pm S D)$.

\begin{tabular}{|c|c|c|c|c|c|c|}
\hline & \multicolumn{2}{|c|}{ Control plants } & \multicolumn{2}{|c|}{ Foliar exposure } & \multicolumn{2}{|c|}{ Root exposure } \\
\hline & Lettuces & Rye-grass & Lettuces & Rye-grass & Lettuces & Rye-grass \\
\hline Total lead concentrations in plant shoots ( $\mathrm{mg} \mathrm{kg}^{-1}$ of dry weight) & $0.69 \pm 0.09$ & $2.67 \pm 1.1$ & $171.5 \pm 5.5^{*}$ & $700.1 \pm 27.5^{*}$ & $35.6 \pm 3.7^{*}$ & $82.4 \pm 6.7^{*}$ \\
\hline Lead global enrichment factors & - & - & $248.7 \pm 10.3$ & $262.2 \pm 8.9$ & $51.6 \pm 4.7$ & $64.2 \pm 3.2$ \\
\hline Lead bioaccumulation factors (soil $\rightarrow$ shoots) & - & - & - & - & 0.018 & 0.041 \\
\hline
\end{tabular}

Notes:

1) Lettuce leaves were rinsed with deionized water before analysis whereas rye-grass was not.

* Significant differences $(\mathrm{p}<0.05)$ compared with control plants. 


\subsection{Pb speciation in leaves determined by XAS}

Fig. 1 shows the XANES and EXAFS spectra for the Pb reference compounds. $\mathrm{Pb}$ malate and $\mathrm{Pb}$ citrate solutions have very similar spectra, but differ from $\mathrm{Pb}$-pectin, which is used as a proxy for $\mathrm{Pb}$ bound to polysaccharides of the cell wall. The chemical form of $\mathrm{Pb}$ in the particles and in the plant tissues was determined by linear combination fits of XANES and EXAFS spectra (Fig. 2 and Table 3). Pristine and aged particles were correctly fitted with a mixture of $\alpha \mathrm{PbO}$ and $\mathrm{PbSO}_{4}$, with a higher proportion of the latter species in the aged particles. For these samples, the sum of percentages determined by EXAFS linear combination fittings (LCF) was well below 100\% (55 and 72\%), which might be due to sample heterogeneities. This effect was not observed in the XANES results, so they were considered more reliable. Anyway, both results point to an increase in $\mathrm{PbSO}_{4}$ during aging, as already reported by Uzu et al. $(2009,2011)$.

The XANES spectrum for the leaves of rye-grass after foliar exposure was best fitted with a mixture of $65 \% \mathrm{~Pb}$-cell wall complexes and $35 \%$ $\mathrm{Pb}$-organic acids ( $\mathrm{Pb}-\mathrm{OAs}$ ). The EXAFS fit showed a slightly different result, with a majority of $\mathrm{Pb}-\mathrm{OAs}$. For the same reason as mentioned above, the XANES fit was considered more reliable, but both results are consistent with a complexation of $\mathrm{Pb}$ by $\mathrm{COOH} / \mathrm{OH}$-containing molecules. For the rye-grass leaves after root exposure, $\mathrm{Pb}$ was present as half pyromorphite, the second half being $\mathrm{Pb}$-cell wall (based on XANES) and undetermined (based on EXAFS). No satisfactory fit was obtained if pyromorphite was excluded, which provides support for the presence of this mineral. For the lettuce leaves after foliar exposure, a majority of $\alpha \mathrm{PbO}$ and $\mathrm{PbSO}_{4}$ was found, and secondary species ( $\mathrm{Pb}-\mathrm{OAs}$ and possibly other species) represented $20 \%$ of total $\mathrm{Pb}$. Finally, due to the relatively low $\mathrm{Pb}$ concentrations in lettuce shoots after root exposure, a XANES spectrum could not be provided for this sample.

\subsection{Pb-enriched area identification by SEM-EDX and RMS characterization}

Lettuce and rye-grass leaves contaminated by atmospheric deposition were analyzed by SEM-EDX and RMS in order to observe the leaf surface morphology and to characterize $\mathrm{Pb}$-containing species possibly present on or near the leaf surface. Large necrotic areas and fine particles were observed on the surface of lettuce leaves by SEM-EDX, and some particles were found within stomata (Supporting information $\mathrm{S} 2$ ). Ca and Mn were mainly detected in necroses and identified by RMS as $\mathrm{CaCO}_{3}$ and $(\mathrm{Ca}, \mathrm{Mn}) \mathrm{CO}_{3}$ species. Fine particles were composed of $\mathrm{Pb}, \mathrm{Ca}, \mathrm{Na}$, and $\mathrm{K}$ or of $\mathrm{Pb}, \mathrm{Ca}, \mathrm{Na}$, and $\mathrm{Fe}$. RMS measurements identified $\mathrm{PbSO}_{4}, \mathrm{PbO} \cdot \mathrm{PbSO}_{4}, \mathrm{CaCO}_{3}, \mathrm{Na}_{2} \mathrm{CO}_{3}$, and $\alpha-\mathrm{Fe}_{2} \mathrm{O}_{3}$ minerals (Fig. 3), which is consistent with XAS results. Typical Raman bands of carbon at $\sim 1300 \mathrm{~cm}^{-1}$ and $\sim 1600 \mathrm{~cm}^{-1}$ were identified in all Raman spectra recorded. Carbon formation is due to the degradation of the cuticular wax by the laser beam.

Detailed observation of stomata located on necroses on BSE images showed some deformation of stomata, which became turgid (Supporting information S2). In many cases a disruption of the guard cells or of the cuticle covering the guard cells was observed, with particles trapped in organic folds (Supporting information S2d). As expected, the elemental composition of non-deformed stomata which were free from particles was mainly $\mathrm{Na}, \mathrm{Mg}, \mathrm{Ca}, \mathrm{K}, \mathrm{Cl}, \mathrm{P}$, and $\mathrm{Mn}$, whereas $\mathrm{Pb}$ was identified within deformed stomata tissues (guard and epidermal cells).

Finally, numerous Pb-rich hexagonal platy crystals were evidenced by SEM-EDX (Fig. 4a and b, detailed view). Cerussite $\left(\mathrm{PbCO}_{3}\right)$ was also identified by RMS with a strong Raman band at $1059 \mathrm{~cm}^{-1}$ related to $\mathrm{CO}_{3}^{2-}$ stretching mode (Fig. 3a). Pb carbonate was also identified in pristine and aged particles but without such a hexagonal morphology.

For rye-grass, a large number of fine individual particles $(<5 \mu \mathrm{m})$ and coarse aggregates were observed by SEM-EDX. Particles or 

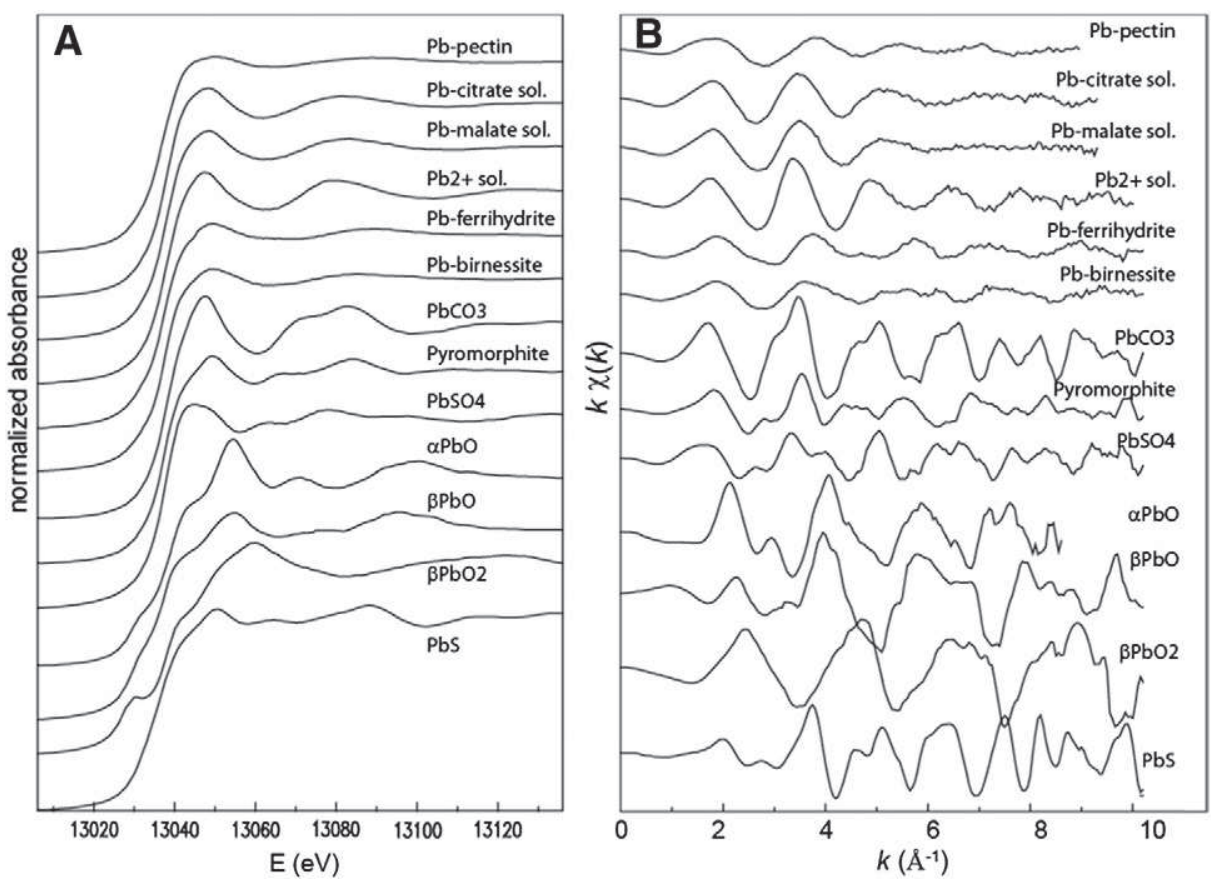

Fig. 1. Pb LIII-edge XANES (a) and EXAFS (b) spectra for Pb reference compounds.

aggregates were found as deposits on the leaf surface or trapped in leaf asperities (Supporting information S3). Elements detected in the leaf tissue included $\mathrm{Na}, \mathrm{Mg}, \mathrm{K}, \mathrm{Ca}, \mathrm{P}, \mathrm{Cl}$, and $\mathrm{Si}$, whereas particles or aggregates were mainly composed of $\mathrm{Pb}, \mathrm{Fe}, \mathrm{S}, \mathrm{Ca}, \mathrm{Na}$, and $\mathrm{Cl}$. The main minerals identified by RMS in particles were $\alpha$-FeOOH, $\mathrm{Fe}_{3} \mathrm{O}_{4}, \mathrm{PbSO}_{4}$, $\mathrm{CaSO}_{4} \cdot 2 \mathrm{H}_{2} \mathrm{O}$, and $\mathrm{CaCO}_{3}$ (Fig. 3b). Finally, the typical Raman bands of carbon were also observed in all the Raman spectra recorded on ryegrass leaf surfaces, showing the degradation of the cuticular wax when particles were analyzed. $\mathrm{PbSO}_{4}$ was often associated with $\mathrm{Fe}$ rich or Ca-rich species, as seen in the molecular image shown in Supporting information S4. Atmospheric particles were often composed of aggregates of Pb-rich species and $\mathrm{Fe}_{2} \mathrm{O}_{3}$ and/or $\mathrm{CaSO}_{4}$ and/or $\mathrm{Na}_{2} \mathrm{SO}_{4}$ as a complex mixture.

\section{Discussion}

4.1. Influence of the plant species on metal transfer and accumulation in shoots

Relatively high $\mathrm{Pb}$ concentrations in leaves were observed for both plant species and both pathways of exposure. For the foliar exposure, a four-fold higher $\mathrm{Pb}$ concentration was observed in the leaves of rye- grass as compared to lettuce (Table 1). This is partly due to the fact that, unlike lettuce leaves, the rye-grass leaves were not washed and might support $\mathrm{Pb}$-rich particles just deposited on the leave surfaces. However, a measure of $\mathrm{Pb}$ concentration in rye-grass after the same washing step as performed for lettuce permits the amount of metal removed to be estimated as $29 \%$. That value is quite consistent with previous studies performed on lettuce samples exposed to similar conditions and showing that the washing procedure removed a maximum of $25 \%$ of the total $\mathrm{Pb}$ (Schreck et al., 2012a,b). Using this percentage (29\%) for rye-grass, the $\mathrm{Pb}$ content for washed rye-grass can be calculated and is about $500 \mathrm{mg} \mathrm{kg}^{-1} \mathrm{DW}$, which is still more than about threefold higher than the content in lettuce. Thus, the foliar uptake of $\mathrm{Pb}$ was considered higher for rye-grass than for lettuce, especially as the BF was higher for rye-grass than for lettuce, and the GEF factors were relatively similar between lettuce and rye-grass.

4.2. Influence of the uptake pathway on $\mathrm{Pb}$ compartmentalization and speciation for each plant species

For rye-grass, EXAFS analysis performed on both foliar and root exposed shoots permits the conclusion that $\mathrm{Pb}$ speciation in leaves differed significantly according to the pollution context. Actually,
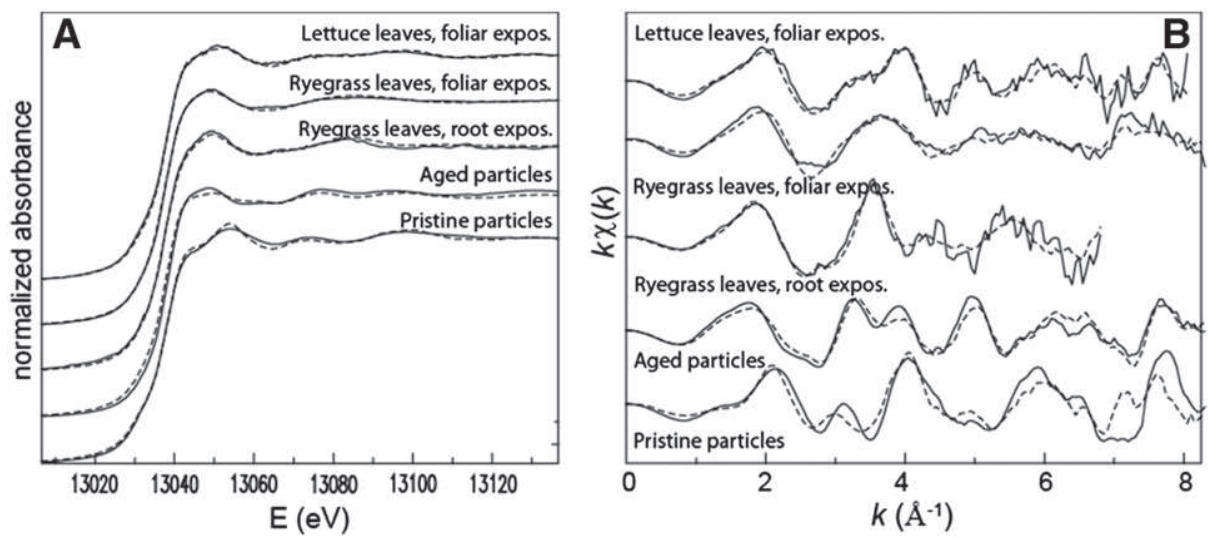

Fig. 2. Pb LIII-edge XANES (a) and EXAFS (b) spectra for the pristine and aged particles and for the plant leaves and linear combination fits (dashed lines). 
Distribution of $\mathrm{Pb}$ species in the particles and in the plant tissues as determined by LCFs of XANES and EXAFS spectra.

\begin{tabular}{|c|c|c|c|c|c|c|c|c|}
\hline & \multicolumn{7}{|c|}{ Molar percentages of $\mathrm{Pb}$ species } & \multirow[b]{2}{*}{$N S S^{\mathrm{d}}$} \\
\hline & $\alpha \mathrm{PbO}$ & $\mathrm{PbSO}_{4}$ & Pyromorphite & $\mathrm{Pb}-\mathrm{OAs} \mathrm{a}^{\mathrm{a}}$ & $\mathrm{Pb}-$ cell wall ${ }^{\mathrm{b}}$ & Undet. $^{c}$ & Sum & \\
\hline Pristine particles, XANES & 52 & 48 & & & & & 100 & 0.014 \\
\hline Pristine particles, EXAFS & 20 & 35 & & & & & 55 & 0.40 \\
\hline Aged particles, XANES & 18 & 81 & & & & & 99 & 0.000 \\
\hline Aged particles, EXAFS & 13 & 42 & & & & 17 & 72 & 0.20 \\
\hline Ryegrass leaves, foliar exposure, XANES & & & & 35 & 65 & & 100 & 0.005 \\
\hline Ryegrass leaves, foliar exposure, EXAFS & 14 & & & 49 & & & 63 & 0.19 \\
\hline Ryegrass leaves, root exposure, XANES & & & 47 & & 54 & & 101 & 0.012 \\
\hline Ryegrass leaves, root exposure, EXAFS & & & 50 & & & 50 & 100 & 0.24 \\
\hline Lettuce leaves, foliar exposure, XANES & 48 & 33 & & 19 & & & 100 & 0.060 \\
\hline Lettuce leaves, foliar exposure, EXAFS & 31 & 31 & & & & 21 & 83 & 0.24 \\
\hline
\end{tabular}

${ }^{\mathrm{a}} \mathrm{Pb}$-organic acid complexes in solution, such as $\mathrm{Pb}$ malate and $\mathrm{Pb}$ citrate.

b $\mathrm{Pb}$-pectin complex was used as a proxy for Pb-cell wall.

c Undetermined means that several fits of equivalent quality were obtained with various species.

${ }^{d}$ Normalized sum-squares residual NSS $=\Sigma\left(\mu_{\text {experimental }}-\mu_{\text {fit }}\right)^{2} / \Sigma\left(\mu_{\text {experimental }}\right)^{2} \times 100$ in the 13,015-13,110 eV range for XANES, and NSS $=\Sigma\left(k^{2} \chi \text { experimental }-k^{2} \chi_{\text {fit }}\right)^{2} /$ $\Sigma\left(k^{2} \chi \text { experimental }\right)^{2} \times 100$ in the $0-8 \AA^{-1}$ range for EXAFS.

after foliar exposure, a majority of $\mathrm{Pb}$-organic species ( $\mathrm{Pb}$ bound to polysaccharides of the cell wall and $\mathrm{Pb}$-organic acids) was observed. $\mathrm{PbSO}_{4}$ identified only by RMS on the leaf surface but not detected by $\mathrm{XAS}$ was classified as a minor species.
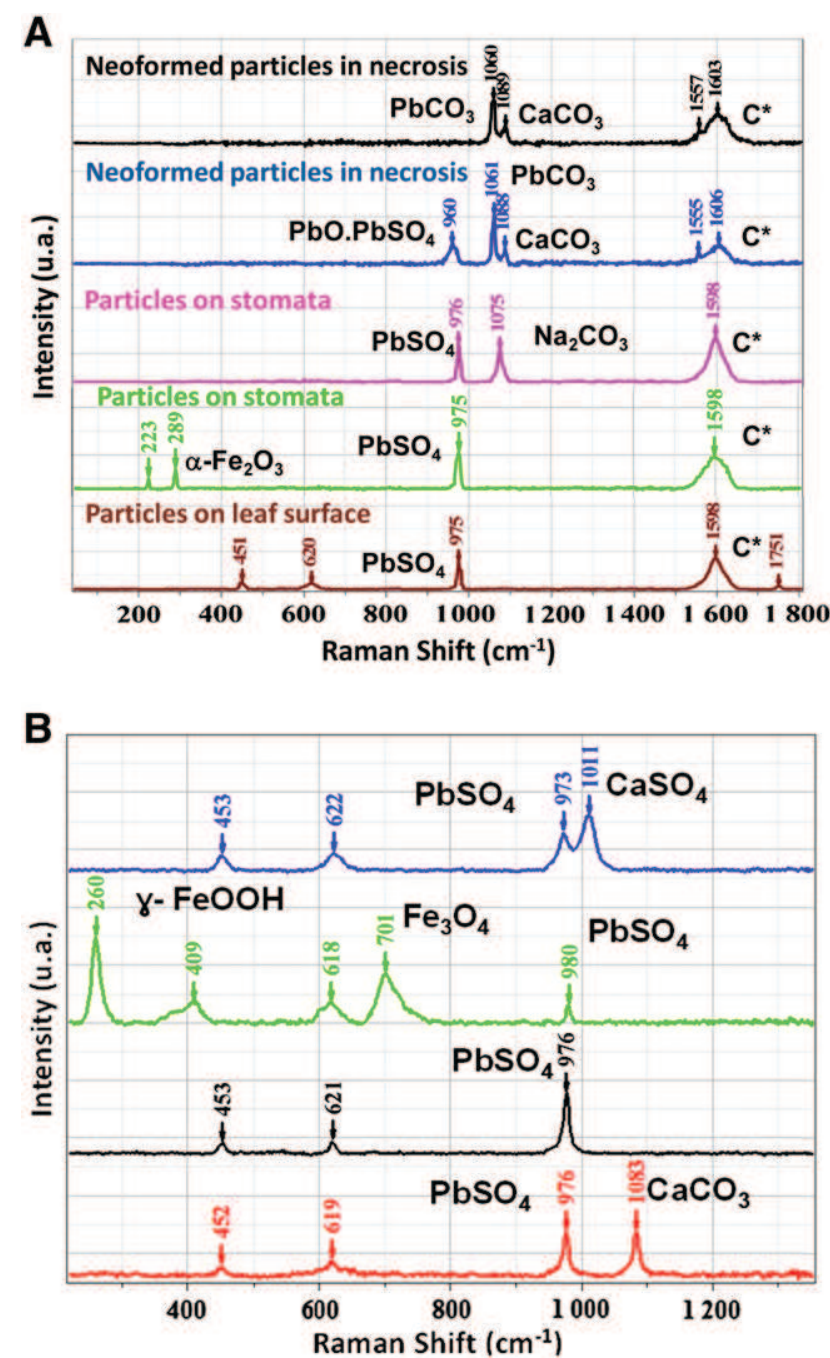

Fig. 3. Typical Raman spectra recorded on the lettuce (a) and rye-grass leaves (b). ( $C^{*}$ is related to Carbon species).
The typical Raman bands of carbon recorded on the rye-grass leaf surface showed the degradation of the cuticular wax when particles were analyzed. This may suggest that particles might also be trapped within the cuticular wax. $\mathrm{PbSO}_{4}$ was often associated with Fe-rich or $\mathrm{Ca}$-rich species, suggesting that $\mathrm{Pb}$-rich particles were often found on the leaf surface as complex aggregates likely trapped in cuticular wax.

Changes in speciation from inorganic to organic species were consistent with LA-ICP-MS results, showing a diffuse Pb concentration on all regions of the leaf (in ga spots). Thus, without any washing process, $\mathrm{Pb}$-rich particles deposited on rye-grass leaf surfaces likely underwent dissolution followed by the transfer of $\mathrm{Pb}$ inside the leaf tissue. In ryegrass leaves after root exposure, pyromorphite and $\mathrm{Pb}$ bound to polysaccharides of the cell wall were the major components. These results suggest that $\mathrm{Pb}$ sequestration mechanisms differ as a function of exposure pathway. Published data on metal speciation in plants mostly concerns root exposure experiments (Becker et al., 2008; Huguet et al., 2012; Tian et al., 2010). The association of Pb with cell wall components was previously observed by EXAFS as the main Pb storage mechanism in the leaves of both accumulator and non-accumulator ecotypes of Sedum alfredii after $\mathrm{Pb}$ root exposure (Tian et al., 2010). The formation of pyromorphite was observed by EXAFS in the leaves of Phaseolus vulgaris after $\mathrm{Pb}$ root exposure (Sarret et al., 2011). A transmission electron microscopy-energy dispersive X-ray (TEM-EDX) study on the roots of the Pbresistant signal grass (Brachiaria decumbens Stapf) and of the $\mathrm{Pb}$ sensitive Rhodes grass (Chloris gayana Kunth) showed the presence of pyromorphite both in the apoplasm and in the vacuoles of root cells, with a higher accumulation of this mineral in the apoplasm of the tolerant species (Kopittke et al., 2007). It is not clear whether the formation of pyromorphite is driven by the plant as a detoxification mechanism or is the result of local supersaturation with $\mathrm{Pb}, \mathrm{P}$, and $\mathrm{Cl}$. Still, this mineral is an efficient trap for $\mathrm{Pb}$ due to its very low solubility. The formation of pyromorphite in Pb-contaminated soils was also observed as a result of root and fungal activities (Laperche et al., 1997; Sayer et al., 1999; Rhee et al., 2012; Shahid et al., 2012). The presence of Pb-organic acid complexes might be interpreted as $\mathrm{Pb}$ sequestration in vacuoles, as previously observed for $\mathrm{Zn}, \mathrm{Ni}$, and $\mathrm{Cd}$ in various plant species (Muschitz et al., 2009; Sarret et al., 2013).

In lettuce, $\mathrm{Pb}$ speciation in leaves after foliar exposure (determined by XAS) was significantly different both from $\mathrm{Pb}$ speciation in pristine particles and from that in rye-grass leaves. Original minerals $(\alpha \mathrm{PbO}$ and $\mathrm{PbSO}_{4}$ ) were still the major species, but organic lead compounds were also observed (minimum amount: 20\%). This latter species may be present in or on the cuticle or inside the leaf. Actually, the incorporation of Pb-rich particles in the leaf tissue has been suggested by the combined experiments used. Moreover, Raman spectra results suggest that particles are embedded in the cuticular wax as previously 

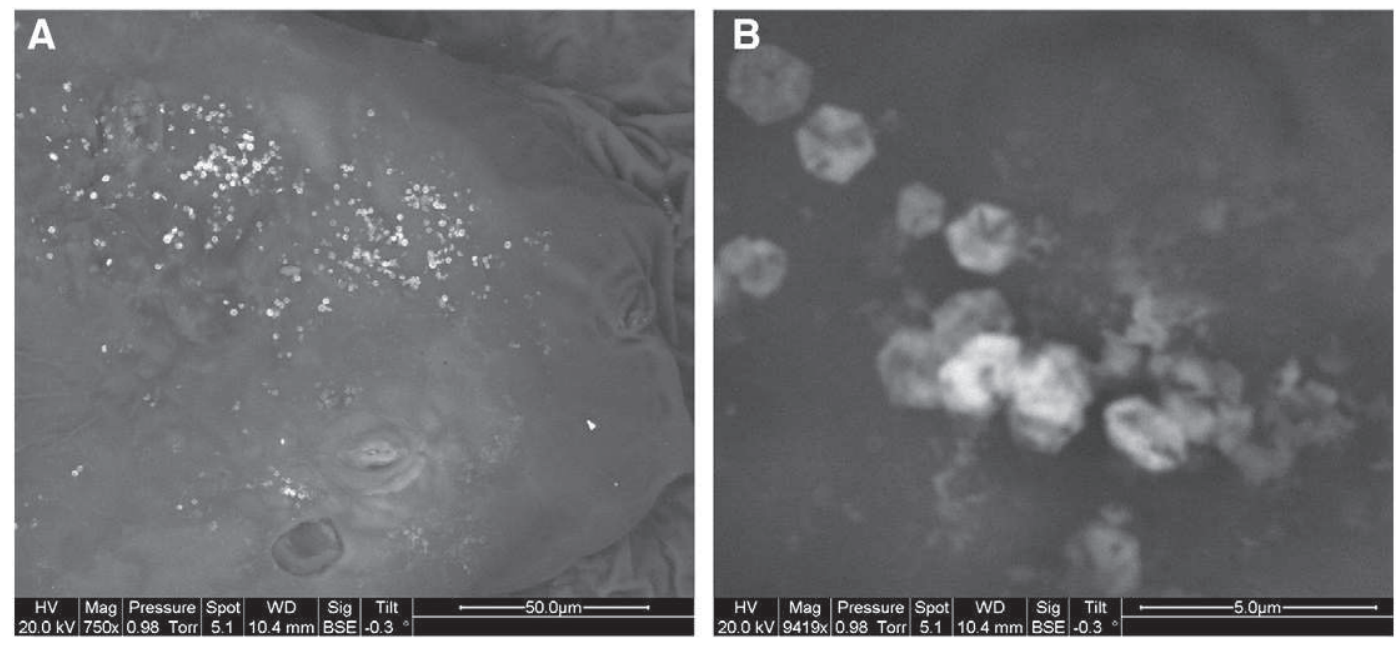

Fig. 4. BSE images of a necrotic area identified on lettuce leaf containing hexagonal $\mathrm{PbCO}_{3}$ particles (a); Detailed view of $\mathrm{PbCO}_{3} \mathrm{Crystals} \mathrm{(b).}$

demonstrated (Schreck et al., 2012a,b). However, this minor proportion of internalized $\mathrm{Pb}$ suggests a limited aging of the particles deposited on the leaf surface and limited transfer of $\mathrm{Pb}$ throughout the leaf. In addition, some hexagonal platy crystals of cerussite $\left(\mathrm{PbCO}_{3}\right)$ were identified on the leaf surface by RMS. The fact that they were not detected by XANES and EXAFS suggests that they represented less than 20\% of total $\mathrm{Pb}$. $\mathrm{Pb}$ carbonates were also identified in pristine and aged particles but this hexagonal morphology has never been observed. The reaction between $\mathrm{PbO}$ and $\mathrm{CO}_{2}$ in a humid atmosphere might lead to the formation of $\mathrm{PbCO}_{3}$ as a coating on a $\mathrm{PbO}$ surface. The formation of pure cerussite particles with a perfect hexagonal morphology implies a solubilization-crystallization process at the leaf surface. The formation of such cerussite hexagonal crystals was described as a result of interaction between micrometer-scale $\mathrm{PbSO}_{4}$ and $\mathrm{CaCO}_{3}$ particles exposed to humidity (Falgayrac et al., 2013) or between $\mathrm{CaCO}_{3}$ and saturated $\mathrm{Pb}^{2+}$ solution (Godelitsas et al., 2003). The formation of these phases could also result from the interaction with biochemical compounds present in the phyllosphere (Rajkumar et al., 2012; Timms-Wilson et al., 2006).

Detailed observations of stomata located in necrotic zones and containing some particles in the stomatal openings showed some deformations of the guard cells. To our knowledge, these kinds of stomatal deformations have never been reported in leaves contaminated by particles. These disruptions attest some toxicity for the stomatal cells, and they probably also perturb the gas exchanges of the plant.

All these results therefore support the hypothesis of a change in $\mathrm{Pb}$ compartmentalization and speciation due to absorption and translocation processes occurring in the plant that would differ depending on the mode of $\mathrm{Pb}$-plant interaction. According to the pathway of lead transfer, several mechanisms are described in the publications; they differ in the rhizosphere in comparison with the phyllosphere. Thus the metal translocation in plants could also differ. In the case of root exposure, the influence of the rhizosphere activity on the status of metals or metalloids in the substrate has been evidenced in many studies (Bravin et al., 2008, 2012; Jouvin et al., 2012; Rajkumar et al., 2012; Panfili et al., 2005; Wenzel, 2009). After root uptake, metals are transferred by the apoplasmic pathway or symplastic transport across the root cortex to plant storage tissues in different ways depending on the plant and metal considered (Colangelo and Guerinot, 2006; Michaud et al., 2007; Tudoreanu and Phillips, 2004). In the case of foliar transfer, particles may be trapped on the leaf surface of plants due to leaf hairs and wax cover (Sæbø et al., 2012), depending on their size (Eichert et al., 2008; Schreck et al., 2012a). Metal-containing particles deposited on the phyllosphere (in direct contact with the atmosphere) are subjected to changes in humidity, temperature, and physico-chemical conditions. Moreover, the phyllosphere hosts an intense microbial activity and is a place of excretion of various inorganic and organic compounds (Lindow and Brandl, 2003; Timms-Wilson et al., 2006). Thus, these mechanisms involved in the rhizosphere and/or the phyllosphere zones could be effectively responsible for the observed metal speciation and compartmentalization changes as a function of the plant species (as, for instance, the nature and quantities of root and foliar exudates depend on the plant considered). In addition, after its plant uptake, the metal may undergo biotransformation in the plant directly in relation to the plant species and certainly as a function of the pathway of transfer.

\subsection{Implications for risk assessment}

The accuracy of human health risk assessment in the case of ingestion of polluted vegetables might be considerably improved by taking into account the compartmentalization and speciation of metals in edible parts of plants. Actually, the relationship between metal speciation and bioaccessibility by ingestion for humans is well recognized in soils (Batista et al., 2011; Denys et al., 2009; Smith et al., 2008). Han et al. (2012) reported that the bioaccessible Pb form was significantly correlated to the Fe-Mn oxides-bound, carbonate, and organically bound $\mathrm{Pb}$ fractions. This is consistent with the fact that these fractions are unstable in an anoxic and reducing environment such as the gastrointestinal tract (Marschner et al., 2006).

The present study suggests that $\mathrm{Pb}$ speciation in plants depends on exposure conditions and plant species. $\mathrm{Pb}$-organic species and $\mathrm{PbCO}_{3}$ identified in plant tissues (and not present in source particles) could represent toxic forms due to their relatively high bioavailability for humans and/or animals.

\section{Conclusions and perspectives}

Exploring the pathway of $\mathrm{Pb}$ transfer at different scales by combining various techniques for two different plant species, the present study shows for the first time that $\mathrm{Pb}$ localization and speciation in plants strongly depend on exposure conditions (atmospheric versus soil) and plant species (i.e., morphology, physiology, home-preparation, and consumption mode).

The complementarity between bulk XAS, which provides the average $\mathrm{Pb}$ speciation and is sensitive to diffuse $\mathrm{Pb}$-organic complexes present in the leaf tissue, and RMS and SEM-EDX, which can detect additional $\mathrm{Pb}$ mineral species present on the leaf surface, even if they account for a minor proportion of the $\mathrm{Pb}$ species, was essential to clarify the fate of metal in plants. Further studies are in progress to better explore the 
link between metal compartmentalization and speciation and its bioavailability and (eco)toxicity and finally their potential implications in terms of risk assessment.

More plant species, metals, and environmental conditions (climatic, pedologic ...) could be investigated in order to assess environmental and health risks and to give special recommendations for the management of polluted sites. Moreover, microbiological studies could bring relevant information to better understand the phenomena involved in the complex rhizosphere and/or phyllosphere interfaces.

\section{Conflict of interest}

All authors disclose any actual or potential conflict of interest including any financial, personal or other relationships with other people or organizations within three years of beginning the submitted work that could inappropriately influence, or be perceived to influence, their work.

\section{Acknowledgments}

We gratefully acknowledge ADEME, the French Agency of the Environment and Energy, for funding the DIMENSION project, as well as STCM Chemical Metal Treatments Company for its technical help in the experimental set-up and financial support. We would like to thank the European Synchrotron Radiation Facility (Grenoble, France) for the provision of beam time and the staff of the FAME beamline at the ESRF for their support during the experiment. LASIR participates in the Research Institute of the Industrial Environment (IRENI), which is financed by the Nord-Pas de Calais Regional Council, the French Ministry of Higher Education and Research, the CNRS, and European funds (FEDER).

\section{Appendix A. Supplementary data}

Supplementary data to this article can be found online at http://dx. doi.org/10.1016/j.scitotenv.2013.12.089.

\section{References}

Batista BL, Souza JMO De Souza SS, Barbosa F. Speciation of arsenic in rice and estimation of daily intake of different arsenic species by Brazilians through rice consumption. J Hazard Mater 2011;191:342-8.

Becker JS, Dietrich RC, Matusch A, Pozebon D, Dressler VL. Quantitative images of metals in plant tissues measured by laser ablation inductively coupled plasma mass spectrometry. Spectrochim Acta, Part B 2008:63:1248-52.

Birbaum K, Brogiolo R, Schellenberg M, Martinoia E, Stark WJ, Günther D, et al. No evidence for cerium dioxide nanoparticle translocation in maize plants. Environ Sci Technol 2010;44:8718-23.

Bravin MN, Travassac F, Le Floch M, Hinsinger P, Garnier JM. Oxygen input controls the spatial and temporal dynamics of arsenic at the surface of a flooded paddy soil and in the rhizosphere of lowland rice (Oryza sativa L.): a microcosm study. Plant Soil 2008;312:207-18

Bravin MN, Garnier C, Lenoble V, Gérard F, Dudal Y, Hinsinger P. Root-induced changes in $\mathrm{pH}$ and dissolved organic matter binding capacity affect copper dynamic speciation in the rhizosphere. Geochim Cosmochim Acta 2012;84:256-68.

Caggiano R, D'Emilio M, Macchiato M, Ragosta M. Heavy metals in rye-grass species versus metal concentrations in atmospheric particulate measured in an industrial area of southern Italy. Environ Monit Assess 2005;102:67-84.

Chopra AK, Pathak C. Enrichment and translocation of heavy metals in soil and Spinacea oleracea grown in sugar mill effluent irrigated soil. Sugar Tech 2013;15:77-83.

Colangelo EP, Guerinot ML. Put the metal to the petal: metal uptake and transport throughout plants. Curr Opin Plant Biol 2006;9(3):322-30.

De Temmerman L, Ruttens A, Waegeneers N. Impact of atmospheric deposition of As, Cd and $\mathrm{Pb}$ on their concentration in carrot and celeriac. Environ Pollut 2012;166:187-95.

Denys S, Tack K, Caboche J, Delalain P. Bioaccessibility, solid phase distribution, and speciation of Sb in soils and in digestive fluids. Chemosphere 2009;74:711-6.

Douay F, Pruvot C, Roussel H, Ciesielski H, Fourrier H, Proix N, et al. Contamination of urban soils in an area of northern France polluted by dust emissions of two smelters. Water Air Soil Pollut 2008:188:247-60.

Eichert T, Kurtz A, Steiner U, Goldbach HE. Size exclusion limits and lateral heterogeneity of the stomatal foliar uptake pathway for aqueous solutes and water-suspended nanoparticles. Physiol Plant 2008;134:151-60.

Estrella-Gómez N, Mendoza-Cózatl D, Moreno-Sánchez R, González-Mendoza D, Zapata-Pérez O, Martínez-Hernández A, et al. The Pb-hyperaccumulator aquatic fern
Salvinia minima Baker, responds to $\mathrm{Pb}^{2+}$ by increasing phytochelatins via changes in SmPCS expression and in phytochelatin synthase activity. Aquat Toxicol 2009;9:320-8. Falgayrac G, Sobanska S, Brémard C. Heterogeneous microchemistry between $\mathrm{CdSO}_{4}$ and $\mathrm{CaCO}_{3}$ particles under humidity and liquid water. J Hazard Mater 2013;248-9: 415-23.

Feng J, Wang Y, Zhao J, Zhu L, Bian X, Zhang W. Source attributions of heavy metals in rice plant along highway in Eastern China. J Environ Sci 2011;23:1158-64.

Gandois L, Tipping E, Dumat C, Probst A. Canopy influence on trace metal atmospheric inputs on forest ecosystems: speciation in throughfall. Atmos Environ 2010;44 824-33.

Godelitsas A, Astilleros JM, Hallam K, Harissopoulos S, Putnis A. Interaction of calcium carbonates with lead in aqueous solutions. Environ Sci Technol 2003;37:3351-60.

Gonzalez-Miqueo L, Elustondo D, Lasheras E, Santamaria JM. Use of native mosses as biomonitors of heavy metals and nitrogen deposition in the surroundings of two steel works. Chemosphere 2010;78:965-71.

Han Z, Bi X, Li Z, Yang W, Wang L, Yang H, et al. Occurrence, speciation and bioaccessibility of lead in Chinese rural household dust and the associated health risk to children. Atmos Environ 2012;46:65-70.

Honour SL, Bell JNB, Ashenden TWA, Cape JN, Power SA. Responses of herbaceous plants to urban air pollution: effects on growth, phenology and leaf surface characteristics. Environ Pollut 2009;157:1279-86

Hu X, Zhang Y, Luo J, Xie M, Wang T, Lian H. Accumulation and quantitative estimates of airborne lead for a wild plant (Aster subulatus). Chemosphere 2011;82:1351-7.

Huguet S, Bert V, Laboudigue A, Barthès V, Isaure MP, Llorens I, et al. Cd speciation and localization in the hyperaccumulator Arabidopsis halleri. Environ Exp Bot 2012;82: $54-65$.

Jouvin D, Weiss DJ, Mason TFM, Bravin MN, Louvat P, Zhao F, et al. Stable isotopes of Cu and $\mathrm{Zn}$ in higher plants: evidence for Cu reduction at the root surface and two conceptual models for isotopic fractionation processes. Environ Sci Technol 2012;46: 2652-60.

Kopittke PM, Asher CJ, Blamey FPC, Menzies NW. Toxic effects of $\mathrm{Pb}^{2+}$ on the growth and mineral nutrition of signal grass (Brachiaria decumbens) and Rhodes grass (Chloris gayana). Plant Soil 2007:300:127-36.

Laperche V, Logan TJ, Gaddam P. Traina SJ. Effect of apatite amendments on plant uptake of lead from contaminated soil. Environ Sci Technol 1997;31:2745-53.

Lei M, Chen TB, Huang ZC, Wang YD, Huang YY. Simultaneous compartmentalization of lead and arsenic in co-hyperaccumulator Viola principis H. de Boiss.: an application of SRXRF microprobe. Chemosphere 2008;72:1491-6.

Lindow SE, Brandl MT. Microbiology of the phyllosphere. Appl Environ Microbiol 2003;69:1875-83.

Marschner B, Welge P, Hack A, Wittsiepe J, Wilhelm M. Comparison of soil Pb in vitro bioaccessibility and in vivo bioavailability with $\mathrm{Pb}$ pools from a sequential soil extraction. Environ Sci Technol 2006;40:2812-8.

Michaud AM, Bravin MN, Galleguillos M, Hinsinger P. Copper uptake and phytotoxicity as assessed in situ for durum wheat (Triticum turgidum durum L.) cultivated in copper-contaminated, former vineyard soils. Plant Soil 2007;298:99-111.

Moffet RC, Desyaterik Y, Hopkins RJ, Tivanski AV, Gilles MK, Wang Y, et al. Characterization of aerosols containing $\mathrm{Zn}, \mathrm{Pb}$, and $\mathrm{Cl}$ from an industrial region of Mexico City. Environ Sci Technol 2008;42:7091-7.

Morman SA, Plumlee GS. The role of airborne mineral dusts in human disease. Aeolian Res 2013;9:203-12.

Munksgaard NC, Parry UDL. Lead isotope ratios determined by ICP-MS: monitoring of mining-derived metal particulates in atmospheric fallout, Northern Territory, Australia. Sci Total Environ 1998:217:113-25.

Muschitz A, Faugeron C, Morvan H. Response of cultured tomato cells subjected to excess zinc: role of cell wall in zinc compartmentation. Acta Physiol Plant 2009;31:1197-204.

Ngole VM. Using soil heavy metal enrichment and mobility factors to determine potential uptake by vegetables. Plant Soil Environ 2011:57:75-80.

Panfili F, Manceau A, Sarret G, Spadini L, Kirpichtchikova T, Bert V, et al. The effect of phytostabilization on $\mathrm{Zn}$ speciation in a dredged contaminated sediment using scanning electron microscopy, X-ray fluorescence, EXAFS spectroscopy and principal components analysis. Geochim Cosmochim Acta 2005:69:2265-84.

Park K, Dam HD. Characterization of metal aerosols in $\mathrm{PM}_{10}$ from urban, industrial, and Asian dust sources. Environ Monit Assess 2010;160:289-300.

Perrone MG, Gualtieri M, Ferrero L, Lo Porto C, Udisti R, Bolzacchini E, et al. Seasonal variations in chemical composition and in vitro biological effects of fine PM from Milan. Chemosphere 2010;78:1368-77.

Piechalak A, Tomaszewska B, Baralkiewicz D, Malecka A. Accumulation and detoxification of lead ions in legumes. Phytochemistry 2002;60:153-62.

Polichetti G, Cocco S, Spinali A, Trimarco V, Nunziata A. Effects of particulate matter $\left(\mathrm{PM}_{10}, \mathrm{PM}_{2.5}\right.$ and $\left.\mathrm{PM}_{1}\right)$ on the cardiovascular system. Toxicology 2009;261:1-8.

Pruvot C, Douay F, Fourrier H, Waterlot C. Heavy metals in soil, crops and grass as a source of human exposure in the former mining areas. J Soil Sediment 2006;6:215-20.

Rajkumar M, Sandhya S, Prasad MN, Freitas H. Perspectives of plant-associated microbes in heavy metal phytoremediation. Biotechnol Adv 2012;30:1562-74.

Raskin I, Kumar PBAN, Dushenkov S, Salt DE. Bioconcentration of heavy metals by plants. Curr Opin Biotechnol 1994:5:285-90.

Ravel B, Newville M. ATHENA and ARTEMIS: interactive graphical data analysis using IFEFFIT. J Synchrotron Radiat 2005;12:537-41.

Rhee YJ, Hillier S, Gadd JM. Lead transformation to pyromorphite by fungi. Curr Biol 2012;22:237-41

Sæbø A, Popek R, Nawrot B, Hanslin HM, Gawronska H, Gawronski SW. Plant species differences in particulate matter accumulation on leaf surfaces. Sci Total Environ 2012;427-8:347-54.

Sammut ML, Noack Y, Rose J, Hazemann JL, Proux O, Depoux M, et al. Speciation of Cd and $\mathrm{Pb}$ in dust emitted from sinter plant. Chemosphere 2010;78:445-50. 
Sarret G, Vangronsveld J, Manceau A, Musso M, D'Haen J, Menthonnex JJ, et al. Accumulation forms of $\mathrm{Zn}$ and $\mathrm{Pb}$ in Phaseolus vulgaris in the presence and absence of EDTA. Environ Sci Technol 2011;35:2854-9.

Sarret G, Pilon Smits EAH, Castillo Michel H, Isaure MP, Zhao FJ, Tappero R. Chapter one use of synchrotron-based techniques to elucidate metal uptake and metabolism in plants. Advances in Agronomy, 119. ; 2013. p. 1-82.

Sayer JA, Cotter-Howells JD, Watson C, Hillier S, Gadd GM. Lead mineral transformation by fungi. Curr Biol 1999;9:691-4.

Schreck E, Foucault Y, Geret F, Pradere P, Dumat C. Influence of soil ageing on bioavailability and ecotoxicity of lead carried by process waste metallic ultrafine particles. Chemosphere 2011:85:1555-62.

Schreck E, Foucault Y, Sarret G, Sobanska S, Cécillon L, Castrec-Rouelle M, et al. Metal and metalloid foliar uptake by various plant species exposed to atmospheric industrial fallout: mechanisms involved for lead. Sci Total Environ 2012a;427-428:253-62.

Schreck E, Bonnard R, Laplanche C, Leveque T, Foucault Y, Dumat C. DECA: a new mode for assessing the foliar uptake of atmospheric lead by vegetation, using Lactuca sativa as an example. J Environ Manage 2012b;112:233-9.

Schreck E, Laplanche C, Le Guédard M, Bessoule JJ, Austruy A, Xiong T, et al. Influence of fine process particles enriched with metals and metalloids on Lactuca sativa L. leaf fatty acid composition following air and/or soil-plant field exposure. Environ Pollut 2013;179:242-9.

Shahid M, Pinelli E, Dumat C. Review of Pb availability and toxicity to plants in relation with metal speciation; role of synthetic and natural organic ligands. J Hazard Mater 2012;219-20:1-12.

Shi G, Chen Z, Teng J, Bi C, Zhou D, Sun C, et al. Fluxes, variability and sources of cadmium, lead, arsenic and mercury in dry atmospheric depositions in urban, suburban and rural areas. Environ Res 2012;113:28-32.

Singh R, Singh DP, Kumar N, Bhargava SK, Barman SC. Accumulation and translocation of heavy metals in soil and plants from fly ash contaminated area. J Environ Biol 2010:31:421-30.

Smith E, Juhasz AL, Weber J, Naidu R. Arsenic uptake and speciation in rice plants grown under greenhouse conditions with arsenic contaminated irrigation water. Sci Total Environ 2008;392:277-83.

Taylor FG, Witherspoon JP. Retention of simulated fallout particles by lichens and mosses. Health Physiol 1972;23:867-76.
Tian S, Lu L, Yang X, Webb S, Du Y, Brown P. Spatial imaging and speciation of lead in the accumulator plant Sedum alfredii by microscopically focused synchrotron X-ray investigation. Environ Sci Technol 2010;44:5920-6.

Timms-Wilson TM, Smalla K, Goodall TI, Houlden A, Gallego V, Bailey MJ. Chapter 2: microbial diversity in the phyllosphere and rhizosphere of field grown crop plants: microbial specialisation at the plant surface. In: Bailey MJ, Lilley AK, Timms-Wilson TM, Spencer-Phillips PTN, editors. Microbial ecology of aerial plant surfaces. CAB International; 2006.

Tomasevic M, Vukmirovic Z, Rajsic S, Tasic M, Stevanovic B. Characterization of trace metal particles deposited on some deciduous tree leaves in an urban area. Chemosphere 2005;61:753-60.

Tudoreanu L, Phillips CJC. Modeling cadmium uptake and accumulation in plants. Adv Agron 2004;84:121-57.

Uzu G, Sobanska S, Aliouane Y, Pradere P, Dumat C. Study of lead phytoavailability for atmospheric industrial micronic and sub-micronic particles in relation with lead speciation. Environ Pollut 2009;157:1178-85.

Uzu G, Sobanska S, Sarret G, Munoz M, Dumat C. Foliar lead uptake by lettuce exposed to atmospheric fallouts. Environ Sci Technol 2010;44:1036-42.

Uzu G, Sobanska S, Sarret G, Sauvain JJ, Pradère $P$, Dumat $C$. Characterization of lead-recycling facility emissions at various workplaces: major insights for sanitary risk assessment. J Hazard Mater 2011;186:1018-27.

Waheed A, Li X, Tan M, Bao L, Liu J, Zhang Y, et al. Size distribution and sources of trace metals in ultrafine/fine/coarse airborne particles in the atmosphere of Shanghai. Aerosol Sci Technol 2011;45:163-71.

Wenzel WW. Rhizosphere processes and management in plant-assisted bioremediation (phytoremediation) of soils. Plant Soil 2009;321:385-408.

Yanqun Z, Yuan L, Schvartz C, Langlade L, Fan L. Accumulation of $\mathrm{Pb}, \mathrm{Cd}, \mathrm{Cu}$ and $\mathrm{Zn}$ in plants and hyperaccumulator choice in Lanping lead-zinc mine area, China. Environ Int 2004;30:567-76.

Zangi R, Filella M. Transport routes of metalloids into and out of the cell: a review of the current knowledge. Chem Biol Interact 2012;197:47-57.

Zhang Z, Gao X, Qiu B. Detection of phytochelatins in the hyperaccumulator Sedum alfredii exposed to cadmium and lead. Phytochemistry 2008;69:911-8. 